\title{
Insulin and insulin-like growth factor I in follicular fluid after induction of ovulation in women undergoing in vitro fertilization
}

 \\ M. Acebal ${ }^{2}$, F. Vergara $^{1}$ and A. Herruzo ${ }^{1}$ \\ ${ }^{1}$ Human Reproduction Unit, Department of Obstetrics and Gynaecology, and ${ }^{2}$ Clinical Analyses \\ Service, Virgen de las Nieves General Hospital, 18014 Granada, Spain
}

\begin{abstract}
Summary. This study was undertaken to evaluate the relationship between concentrations of insulin and insulin-like growth factor I (IGF-I) in follicular fluid and fertilization and cleavage of human oocytes fertilized in vitro. The concentration of oestradiol, progesterone, luteinizing hormone, follicle-stimulating hormone, testosterone, insulin and IGF-I was determined in 36 follicular fluids, free of visible blood contamination and containing mature oocyte-corona-cumulus complexes, obtained from 12 women undergoing in vitro fertilization. Follicular development was induced by clomiphene citrate and human menopausal gonadotrophin, and follicular aspiration was performed $35 \mathrm{~h}$ after an ovulatory dose of human chorionic gonadotrophin. Concentrations of IGF-I were significantly higher in follicular fluids associated with mature oocytes that fertilized and cleaved, than in follicular fluid associated with mature oocytes that did not fertilize $(P<0.001)$. There was no difference in the concentration of insulin between follicular fluids from which fertilized oocytes were obtained and those with oocytes that remained unfertilized. No significant correlations were found between rates of embryo cleavage, concentrations of insulin and IGF-I. Multiple linear regression analysis demonstrated that the concentrations of IGF-I in follicular fluid were predicted statistically by a negative regression coefficient for the concentration of testosterone, and by a positive regression coefficient for the concentration of progesterone in follicular fluid. No candidate variable was included in the model to predict concentrations of insulin. These data suggest an important role for IGF-I in the mature follicle.
\end{abstract}

Keywords: follicular fluid; insulin; insulin-like growth factor $\mathrm{I}$; in vitro fertilization; human

\section{Introduction}

Several reports have indicated that growth factors are involved in paracrine and autocrine regulation in the ovary (Adashi et al., 1985; Dorrington et al., 1987; Tonetta \& diZerega, 1989). Insulin and insulin-like growth factor I are present in follicular fluid, and their role in ovarian steroid synthesis and metabolism has been studied in detail in recent years (Erickson et al., 1989; Holtorf et al., 1989; Reed \& James, 1989; Geisthovel et al., 1990). Although much is known of the action of these substances on theca and granulosa cells, very little is known of the relationship between the concentration of insulin and IGF-I in human follicular fluid and parameters of oocyte quality such as fertilizability and cleavage.

The concentration of insulin has been reported to be higher in the follicular fluid of unfertilized oocytes than in the fluid of fertilized oocytes (Diamond et al., 1985), although Ben-Rafael $e t a l$. (1987) were unable to confirm this. These authors showed that insulin concentrations in follicular 
fluid were not related to the outcome of in vitro fertilization (IVF) of mature oocytes. Conflicting results have also been reported for the relationship between human follicular fluid IGF-I and oocyte maturity, and between the former and IVF outcome (Eden et al., 1988, 1990; Geisthovel et al., 1989; Roussie et al., 1989; Barreca et al., 1990; Rabinovici et al., 1990; Giudice et al., 1990; Hamori et al., 1991; Suchanek et al., 1991).

In an attempt to broaden our understanding of intraovarian regulation, we studied the relationship between the concentrations of insulin and IGF-I in follicular fluid, the concentrations of steroid and gonadotrophin in follicular fluid, and the fertilization and cleavage of human oocytes fertilized in vitro.

\section{Materials and Methods}

\section{Patients}

Thirty-six samples of follicular fluid from 12 infertile women with irreparable tubal damage were aspirated at laparoscopic oocyte collection for IVF. The patients ranged in age from 26 to 37 years, with a mean of $30 \cdot 4$ years. Follicular growth was stimulated by administration of $100 \mathrm{mg}$ of clomiphene citrate (CC Omifin: Merrell Dow, Madrid) for five consecutive days beginning on the third day of the menstrual cycle and human menopausal gonadotrophin (hMG; Pergonal: Serono, Madrid) from the seventh day of the menstrual cycle in decreasing doses (from 225 to 75 iu per day) (Molina et al., 1989). Follicular growth was monitored by measuring daily serum concentrations of oestradiol and by the development of follicles measured ultrasonically from the seventh day. When oestradiol output reached 300 to $400 \mathrm{pg} \mathrm{ml}^{-1}$ per growing follicle $(18 \mathrm{~mm}$ in diameter), 5000 iu human chorionic gonadotrophin (hCG; Profasi: Serono, Madrid) was given, and laparoscopy under general anaesthesia for oocyte retrieval was performed $35 \mathrm{~h}$ later, after an overnight fast. Ten millilitres of blood were obtained from an anticubital vein before anaesthesia for determination of insulin and IGF-I plasma concentrations.

The laboratory procedures following oocyte recovery have been described previously and were not varied throughout the duration of this study (Molina et al., 1989). Follicular fluid free from visible blood contamination and containing only mature oocyte-corona-cumulus complexes was used in further analyses. The follicular fluid specimens were centrifuged at $1500 \mathrm{~g}$ for $10 \mathrm{~min}$ immediately, and aliquots of the cell-free supernatant were frozen and stored until assayed for hormone and IGF-I content.

The oocytes were inseminated with spermatozoa at a concentration of $5-10 \times 10 \mathrm{ml}^{-1}$. All semen samples satisfied the World Health Organization criteria of normality (sperm counts, motility and morphology) (WHO, 1987), and it was confirmed that all semen samples used had fertilized at least one oocyte. Normal fertilization was confirmed microscopically by the observation of two polar bodies and two pronuclei $14-16 \mathrm{~h}$ after insemination. The stage of embryo development was assessed by the rate of cleavage $36-40 \mathrm{~h}$ after insemination. The follicular fluid samples were divided into three groups according to oocyte development after IVF as follows: all follicles containing unfertilized oocytes $(n=12)$, all follicles yielding ova that were fertilized and cleaved to less than four cells $(n=12)$, and follicles yielding ova that were fertilized and cleaved to four or more cells $(n=12)$.

\section{Hormones and IGF-I assays}

Concentrations of luteinizing hormone (LH) and follicle-stimulating hormone (FSH) were measured with commercial enzyme-immunoassay kits (Terumo Medical Corporation, Elkton, MD). Respective intra- and interassay coefficients of variation were 7.2 and $8.3 \%$, for $\mathrm{LH}$, and 6.1 and $8.9 \%$ for FSH. Oestradiol, progesterone and testosterone determinations were performed with radioimmunoassay (RIA) kits (Diagnostic Products Corporation, Los Angeles, CA). Respective intra- and interassay coefficients of variation were 6.8 and $9.9 \%$ for oestradiol, 8.0 and $8.7 \%$ for progesterone, and 6.3 and $9 \cdot 1 \%$ for testosterone. Insulin was measured in serum and follicular fluid with a highly specific RIA, using a kit for Sorin Biomédica (Vercelli, Italy). IGF-I was measured with a commercially available RIA kit (Nichols Institute Diagnostics, San Juan Capistrano, CA) on diluted unextracted samples as described by Roussie et al. (1989). Sensitivities and intra- and interassay coefficients of variation were $2 \cdot 2 \mu \mathrm{U} \mathrm{ml}^{-1}$, 6.8 and $7.0 \%$ for insulin and 0.1 iu ml ${ }^{-1}, 6.0$ and $9.6 \%$ for IGF-I. Crossreactivity of the insulin antiserum with human C-peptide was $<0.01 \%$, and of the IGF-I antiserum with hCG, LH and prolactin were $<0.01,<0.01$ and $<0.02 \%$, respectively.

\section{Statistical analyses}

The results are presented as means \pm standard error of the mean (SEM). After multiple analysis of variance, comparisons were done with Scheffe's and Tukey's test. Significance was defined as $P<0.05$. To predict insulin and IGF-I concentrations in follicular fluid, stepwise multiple regression was used. The variable 'oestradiol' was strongly correlated with the other explanatory variables; therefore, to avoid problems of multicolinearity, oestradiol was 
omitted (Armitage \& Berry, 1987). In the stepwise multiple regression analysis, a variable was included if its partial regression coefficient was significant at the 0.05 level and was eliminated if its partial regression coefficient failed to reach significance at the $0 \cdot 10$ level. Statistical analyses were performed using the BMDP statistical package (BMDP Statistical Software, Los Angeles, CA).

\section{Results}

The mean concentrations of insulin and IGF-I in peripheral blood at the time of oocyte retrieval were significantly higher than the concentrations in follicular fluid (Table 1). Concentrations of IGF-I were significantly higher in follicular fluids associated with mature oocytes that fertilized and cleaved $\left(0.84 \pm 0.03 \mathrm{iu} \mathrm{ml}^{-1}\right)$, than in fluids associated with mature oocytes that did not fertilize $\left(0.43 \pm 0.06 \mathrm{iu} \mathrm{ml}^{-1} ; P<0.001\right)$. There was no difference in the concentration of insulin in follicular fluids from which fertilized oocytes were obtained and those with oocytes that remained unfertilized $\left(6.12 \pm 0.23 \mu \mathrm{U} \mathrm{ml}^{-1}\right.$ versus $\left.5.93 \pm 0.37 \mu \mathrm{U} \mathrm{ml}^{-1}\right)$. No significant correlation was found between rates of embryo cleavage and concentrations of insulin and IGF-I in follicular fluid.

Table 1. Concentrations of insulin and IGF-I in human peripheral blood and follicular fluid

\begin{tabular}{lccc}
\hline & $n$ & $\begin{array}{c}\text { Insulin } \\
\left(\mu \mathrm{ml}^{-1}\right)\end{array}$ & $\begin{array}{c}\text { IGF-I } \\
\left(\mathrm{iu} \mathrm{ml}^{-1}\right)\end{array}$ \\
\hline $\begin{array}{l}\text { Peripheral blood } \\
\text { Follicular fluid }\end{array}$ & 12 & $9.32 \pm 0.50$ & $1.60 \pm 0.09$ \\
& 36 & $6.02 \pm 0.20$ & $0.70 \pm 0.04^{\mathrm{a}}$ \\
Unfertilized & 12 & $5.93 \pm 0.37$ & $0.43 \pm 0.06$ \\
Fertilized & 24 & $6.12 \pm 0.23$ & $0.84 \pm 0.03^{\mathrm{a}}$ \\
$\begin{array}{l}\text { Slow cleavage rate } \\
\text { Fast cleavage rate }\end{array}$ & 12 & $6.19 \pm 0.32$ & $0.84 \pm 0.05$ \\
\hline
\end{tabular}



Concentrations of oestradiol, progesterone, LH and testosterone in follicular fluid associated with oocytes that fertilized were higher than in those associated with oocytes that did not fertilize. No significant differences in concentrations of FSH in follicular fluid were found between the group of fertilized and unfertilized oocytes. The testosterone content in follicular fluid from fertilized oocytes was significantly lower than in follicular fluid of unfertilized oocytes (Table 2). No significant correlation was found between rates of embryo cleavage and concentrations of steroid hormones and gonadotrophins.

Multiple linear regression analysis demonstrated that the concentration of IGF-I in follicular fluid was predicted statistically by a negative regression coefficient for the concentration of

Table 2. Comparisons between concentrations of steroid and gonadotrophic hormones in human follicular fluid associated with mature oocytes that were fertilized $(n=24)$ and that were not fertilized $(n=12)$

\begin{tabular}{llcccc}
\hline Group & $\begin{array}{c}\text { Oestradiol } \\
\left(\mathrm{ng} \mathrm{ml}^{-1}\right)\end{array}$ & $\begin{array}{c}\text { Progesterone } \\
\left(\mathrm{ng} \mathrm{ml}^{-1}\right)\end{array}$ & $\begin{array}{c}\text { Luteinizing } \\
\text { hormone } \\
\left(\mathrm{mU} \mathrm{ml}^{-1}\right)\end{array}$ & $\begin{array}{c}\text { Follicle-stimulating } \\
\text { hormone } \\
\left(\mathrm{mU} \mathrm{ml}^{-1}\right)\end{array}$ & $\begin{array}{c}\text { Testosterone } \\
\left(\mathrm{ng} \mathrm{ml}^{-1}\right)\end{array}$ \\
\hline Unfertilized & $611 \pm 45$ & $1247 \pm 35$ & $2 \cdot 9 \pm 0 \cdot 5$ & $11 \cdot 3 \pm 2 \cdot 3$ & $2 \cdot 3 \pm 0 \cdot 2$ \\
Fertilized & $944 \pm 42^{\mathrm{a}}$ & $1519 \pm 43^{\mathrm{b}}$ & $9 \cdot 5 \pm 0 \cdot 7^{\mathrm{b}}$ & $13 \cdot 8 \pm 0 \cdot 8$ & $1 \cdot 2 \pm 0 \cdot 1^{\mathrm{a}}$ \\
\hline
\end{tabular}

aSignificantly different $(P<0.005)$.

'Significantly different $(P<0.001)$. 
testosterone and by a positive regression coefficient for the concentration of progesterone in follicular fluid (Table 3). No candidate variable was included in the model to predict concentrations of insulin.

\section{Discussion}

The concentration of insulin was significantly lower in preovulatory human follicular fiuid than in peripheral blood. That low basal concentrations of insulin may be necessary for normal folliculogenesis is suggested by the fact that with hyperinsulinaemia, follicular development is arrested in the early or middle stage of development (Sadler \& Maller, 1987). The lower concentration in follicular fluid may be due to a regulatory effect of insulin (Zeleznik \& Roth, 1978) or to an increase in local insulin degradation by way of other (non-receptor) pathways (Berman et al., 1980).

This study shows that concentrations of insulin are similar in preovulatory follicles regardless of the outcome of IVF of mature oocytes and are not related to steroid hormone and gonadotrophin concentrations in follicular fluid. These results are in agreement with the findings of Ben-Rafael et al. (1987) but not with those of Diamond et al. (1985). These differences may be due to the inclusion, in the latter study, of oocytes of different maturities. Insulin appears to play an important role in initial oocyte maturation, as assessed by germinal vesicle breakdown and polar body extrusion (Tsafriri \& Channing, 1975; Lessman \& Schuetz, 1981).

In agreement with previous reports (Adashi et al., 1985; Eden et al., 1988; Geisthovel et al., 1989; Rabinovici et al., 1990; Giudice et al., 1990; Hamori et al., 1991), we found that the concentration of IGF-I was significantly lower in preovulatory follicular fluid than in peripheral blood. Increased IGF-I in peripheral blood and follicular fluid has been associated with polycystic ovaries (Eden et al., 1990; Iwashita et al., 1990). The source of IGF-I in human follicular fluid is unknown. Although circumstantial evidence suggests that IGF-I may be synthesized and secreted by the granulosa cells (Adashi et al., 1985; Geisthovel et al., 1990), no definitive studies in humans have been published. The strong positive correlation reported by different authors (Geisthovel et al., 1989; Rabinovici et al., 1990; Hamori et al., 1991) between plasma and follicular fluid IGF-I concentrations suggests that intrafollicular IGF-I is derived mostly from the circulating pool. Our values for IGF-I in follicular fluid may have been overestimated as IGF-I binding proteins can cause falsely increased concentrations of IGF-I (Daughaday et al., 1987). However, Roussie et al. (1989) have shown that measurements of IGF-I in diluted unextracted follicular fluid provide adequately reliable recovery rates and an acceptable degree of reproducibility.

We noted that follicles containing mature oocytes that failed to fertilize in vitro had lower concentrations of IGF-I than those with oocytes that fertilized. These results contrast with the findings of Rabinovici et al. (1990) and Suchanek et al. (1991), a discrepancy that may be attributed to the use of different stimulation protocols, given that the concentration of IGF-I in serum (Gadd et al., 1991) and preovulatory follicular fluid is influenced by the method of ovarian stimulation (Roussie et al., 1989). Our results confirm previous data regarding the role of IGF-I in oocyte maturation. Human and rat oocytes contain receptors for IGF-I (Andersson et al., 1986; Balboni et al., 1987) and IGF-I has been shown to induce in vitro oocyte maturation (Sadler \& Maller, 1987). Roussie et al. (1989) showed that IGF-I concentrations were higher in follicular fluids yielding a mature oocyte than in those yielding an immature oocyte.

Granulosa cells contain receptors for IGF-I, suggesting that IGF-I acts on granulosa cells in an autocrine fashion (Adashi et al., 1985; Gates et al., 1987). The relationship we found between the concentration of IGF-I and progesterone in follicular fluid is easily explained by recent studies showing that IGF-I modulates key steps in progesterone biosynthesis. Basal progesterone secretion by granulosa cells is enhanced by IGF-I (Davoren et al., 1985; Veldhuis et al., 1986), while the catabolism of progesterone to 20- $\alpha$-hydroxy-progesterone under IGF-I treatment is reduced (Adashi et al., 1985). Other authors have also documented an association between the 
Table 3. Stepwise multiple regression analysis of concentration of IGF-I in human follicular fluid

\begin{tabular}{|c|c|c|c|c|c|c|c|c|}
\hline \multicolumn{6}{|c|}{ Variables in equation } & \multicolumn{3}{|c|}{ Variables not in equation } \\
\hline Step & Variable & Coefficient & $R^{\mathrm{a}}$ & $R^{2}$ & $F_{\text {exp }}$ & Variable & $\begin{array}{c}\text { Partial } \\
\text { correlation }\end{array}$ & $F_{\text {exp }}$ \\
\hline 1 & Testosterone & $-0 \cdot 1274$ & 0.668 & $0 \cdot 446$ & $27 \cdot 40^{\mathrm{b}}$ & Luteinizing hormone & 0.2895 & $2 \cdot 93$ \\
\hline \multirow[t]{2}{*}{2} & Progesterone & $0.4 \times 10^{-3}$ & $0 \cdot 726$ & 0.527 & $5 \cdot 66^{\mathrm{b}}$ & $\begin{array}{l}\text { Follicle-stimulating } \\
\text { hormone }\end{array}$ & $0 \cdot 2249$ & $1 \cdot 70$ \\
\hline & Constant & $0 \cdot 2660$ & & & & Insulin & $-0 \cdot 1361$ & 0.60 \\
\hline
\end{tabular}

${ }^{a} \mathrm{R}$ : multiple correlation coefficient.

'Significantly different $(P<0.01)$.

concentration of IGF-I in follicular fluid and parameters of granulosa cell function (Roussie et al., 1989; Eden et al., 1988, 1989, 1990; Rabinovici et al., 1990). The negative correlation between IGF-I and testosterone concentrations may reflect the fact that IGF-I potentiates FSH-induced aromatase activity by enhancing the reaction velocity but not the substrate affinity of this enzyme complex (Adashi et al., 1985).

We observed no relationship between the concentration of insulin and IGF-I in follicular fluid. However, insulin may regulate the biological action of IGF-I by modulating the concentration of IGF-l-binding proteins (Iwashita et al., 1990). At least three (Giudice et al., 1990) or four (Holly et al., 1990) discrete IGF-I binding proteins are present in human follicular fluid. Some studies have shown that binding proteins increase the amount of IGF-I that binds to IGF receptors (Clemmons et al., 1986), thereby enhancing the response to the growth factor (Elgin et al., 1987), whereas other studies have shown that the binding proteins inhibit IGF-I binding to its receptor, thus attenuating its action (Elgin et al., 1987; Ritvos et al., 1988).

No significant differences were observed in the concentration of insulin and IGF-I between follicular fluids that yielded fertilized oocytes that cleaved to fewer than four cells at $43 \mathrm{~h}$ after insemination and samples containing fertilized oocytes that cleaved to four or more cells. Follicular concentrations of insulin and IGF-I do not predict the cleavage rate of fertilized oocytes. The mechanisms involved in the early cleavage of the human embryo remain unclear but it is obvious that they are not only oocytic in nature.

In conclusion, the concentration of insulin in preovulatory follicular fluid containing mature oocytes was a poor predictor of the ability of oocytes to fertilize. However, the concentration of IGF-I was positively correlated with the ability of the oocyte to fertilize. Thus the concentration of IGF-I in preovulatory follicular fluid may be an indicator of optimal follicular development and oocyte maturation, at least in cycles stimulated by $\mathrm{CC} / \mathrm{hMG} / \mathrm{hCG}$.

We thank Ms K. Shashok for revising the English of the manuscript.

\section{References}

Adashi, E.Y., Resnick, C.E., D'Ercole, J., Svoboda, M.E. \& Van Wyk, J.J. (1985) Insulin-like growth factors as intraovarian regulators of granulosa cell growth and function. Endocrine Reviews 6, 400-420.

Andersson, I., Billig, H., Fryklund, L., Hansson, H.A., Isaksson, O., Isgaard, J., Nilsson, A., Rozell, B., Skottner, A. \& Stemme, S. (1986) Localization of IGF-I in adult rats. Immunohistochemical studies. Acta Physiologica Scandinavica 126, 311-312.

Armitage, P. \& Berry, G. (1987) Multiple measurements. In Statistical Methods in Medical Research, pp.
296-357. Eds P. Armitage \& G. Berry. Blackwell Scientific Publications, Oxford.

Balboni, G.C., Vannelli, G.B., Barni, T., Orlando, C. \& Serio, M. (1987) Transferrin and somatomedin C receptors in the human ovarian follicles. Fertility and Sterility 48, 796-801.

Barreca, A., Minuto, A., Volpe, A., Ceccheli E., Cella, F., Del Monte, P., Artini, P. \& Giordano, G. (1990) Insulin-like growth factor-I (IGF-I) and IGF-I binding protein in the follicular fluids of growth hormone treated patients. Clinical Endocrinology 32, 497-505. 
Ben-Rafael, Z., Meloni, F., Strauss, J.F., Blasco, L., Mastroianni, L. \& Flickinger, G.L. (1987) Relationships between polypronuclear fertilization and follicular fluid hormones in gonadotropin-treated women. Fertility and Sterility 47, 284-288.

Berman, M., McGuire, E.A., Roth, J. \& Zeleznik, A.J. (1980) Kinetic modeling of insulin binding to receptors and degradation in vivo in the rabbit. Diabetes 29, 50-59.

Clemmons, P.R., Elgin, R.G., Han, V.K., Lasella, S.J., D'Ercole, A.J. \& Van Wyk, J.J. (1986) Cultured fibroblast monolayers secrete a protein that alters the cellular binding of somatomedin-C/insulin-like growth factor I. Journal of Clinical Investigation 77 , $1548-1556$.

Daughaday, W.H., Kapadia, M. \& Mariz, I. (1987) Serum somatomedin binding proteins: physiologic significance and interference in radioligand assay. Journal of Laboratory and Clinical Medicine 109, 355-363.

Davoren, J.B., Hsueh, A.J. \& Li, C.H. (1985) Somatomedin C augments FSH-induced differentiation of cultured rat granulosa cells. American Journal of Physiology 249, E26-E33.

Diamond, M.P., Webster, B.W., Carr, R.K., Wentz, A.C. \& Osteen, K.G. (1985) Human follicular fluid insulin concentrations. Journal of Clinical Endocrinology and Metabolism 61, 990-992.

Dorrington, J.H., Bendell, J.J., Chuma, A. \& Lobb D.K. (1987) Actions of growth factors in the follicle. Journal of Steroid Biochemistry 27, 405-411.

Eden, J.A., Jones, J., Carter, G.D. \& Alaghband-Zadeh, J. (1988) A comparison of follicular fluid levels of insulin-like growth factor- 1 in normal dominant and cohort follicles, polycystic and multicystic ovaries. Clinical Endocrinology 29, 327-336.

Eden, J.A., Carter, G.D., Jones, J. \& Alaghband-Zadeh, J. (1989) Insulin-like growth factor 1 as an intraovarian hormone. An integrated hypothesis and review. Australian and New Zealand Journal of Obstetrics and Gynaecology 29, 30-37.

Eden, J.A., Jones, J., Carter, G.D. \& Alaghband-Zadeh, J. (1990) Follicular fluid concentrations of insulinlike growth factor 1, epidermal growth factor, transforming growth factor-alpha and sex-steroids in volume matched normal and polycystic human follicles. Clinical Endocrinology 32, 395-405.

Elgin, R.G., Busby, W.H. \& Clemmons, D.R. (1987) An insulin-like growth factor (IGF) binding protein enhances the biologic response to IGF-I. Proceedings of the National Academy of Sciences of the United States of America 84, 3254-3259.

Erickson, G.F., Garzo, V.G. \& Magoffin, D.A. (1989) Insulin-like growth factor-I regulates aromatase activity in human granulosa and granulosa luteal cells. Journal of Clinical Endocrinology and Metabolism 69, 716-724.

Gadd, S.C., Anthony, F.W., Jenkins, J.M., Davies, D.W. \& Masson, G.M. (1991) Alteration of serum IGF-I concentrations in IVF patients treated with buserelin. Human Reproduction 6, Supplement 1. 74, Abstract P51.

Gates, G.S., Bayer, S., Seibel, M., Poretsky, L., Flier, J.S. \& Moses, A.C. (1987) Characterization of insulin-like growth factor binding to human granulosa cells obtained during in vitro fertilization. Journal of Receptor Research 7, 885-902.

Geisthovel, F., Moretti-Rojas, I.M., Rojas, F.J. \& Asch, R.H. (1989) Immunoreactive insulin-like growth factor I in human follicular fluid. Human Reproduction 4, 35-38.

Geisthovel, F., Moretti-Rojas, I., Rojas, F.J. \& Asch, R.H. (1990) Insulin-like growth factors and thecalgranulosa-cell function. Human Reproduction 5, 785-799.

Giudice, L.C., Farrell, E.M., Pham, H. \& Rosenfeld, R.G. (1990) Identification of insulin-like growth factorbinding protein-3 (IGFBP-3) and IGFBP-2 in human follicular fluid. Journal of Clinical Endocrinology and Metabolism 71, 1330-1338.

Hamori, M., Blum, W.F., Török, A., Stehle, R., Waibel, E., Cledon, P. \& Ranke, M.B. (1991) Insulin-like growth factors and their binding proteins in human follicular fluid. Human Reproduction 6, 313-318.

Holly, J.M., Eden, J.A., Alaghband-Zadeh, J., Carter, G.D., Jemmott, R.C., Cianfarani, S., Chard, T. \& Wass, J.A. (1990) Insulin-like growth factor binding proteins in follicular fluid from normal dominant and cohort follicles, polycystic and multicystic ovaries. Clinical Endocrinology 33, 53-64.

Holtorf, A.P., Furuya, K., Ivell, R. \& McArdle, C.A. (1989) Oxytocin production and oxytocin messenger ribonucleic acid levels in bovine granulosa cells are regulated by insulin and insulin-like growth factor-I: dependence on developmental status of the ovarian follicle. Endocrinology 125, 2612-2620.

Iwashita, M., Mimuro, T., Watanabe, M., Setoyama, T., Matsuo, A., Adachi, T., Takeda, Y. \& Sakamoto, S. (1990) Plasma levels of insulin-like growth factor-I and its binding protein in polycystic ovary syndrome. Hormone Research 33, 21-26.

Lessman, C.A. \& Schuetz, A.W. (1981) Role of follicle wall in meiosis reinitiation induced by insulin in Rana pipiens oocytes. American Journal of Physiology 241, E51-E56.

Molina, R., Castilla, J.A., Vergara, F., Perez, M., Garrido, F. \& Herruzo, A. (1989) Luteal cytoplasmic estradiol and progesterone receptors in human endometrium: in vitro fertilization and normal cycles. Fertility and Sterility 51, 976-979.

Rabinovici, J., Dandekar, P., Angle, M.J., Rosenthal, S. \& Martin, M.C. (1990) Insulin-like growth factor I (IGF-I) levels in follicular fluid from human preovulatory follicles: correlation with serum IGF-I levels. Fertility and Sterility 54, 428-433.

Reed, M.J. \& James, H.T. (1989) Regulation of steroid synthesis and metabolism by growth factors. Clinical Endocrinology 31, 511-525.

Ritvos, O., Ranta, T., Jalkanen, J., Suikkari, A-M., Voutilainen, R., Bohn, H. \& Rutanen, E-M. (1988) Insulin-like growth factor (IGF) binding protein from human decidua inhibits the binding and biological action of IGF-I in cultured choriocarcinoma cells. Endocrinology 122, 2150-2157.

Roussie, M., Royère, D., Guillonueau, M., Lansac, J. \& Muh, J.P. (1989) Human antral fluid IGF-I and oocyte maturity: effect of stimulation therapy. Acta Endocrinologica 121, 90-94. 
Sadler, S.E. \& Maller, J.L. (1987) In vivo regulation of cyclic AMP phosphodiesterase in Xenopus oocytes. Journal of Biological Chemistry 22, $10644-10650$.

Suchanek, E., Simunic, V., Grizelj, V., Halimi, V., Hlavati, V., Dobec, D. \& Zaninovic, N. (1991) Insulinlike growth factor-I levels in human preovulatory follicular fluid. Human Reproduction 6, Supplement 1. 101, Abstract P130.

Tonetta, S.A., \& diZerega, G. (1989) Intragonadal regulation of follicular maturation. Endocrine Reviews 10, 205-229.

Tsafriri, A. \& Channing, C.P. (1975) Influence of follicular maturation and culture conditions on the meiosis of pig oocytes in vitro. Journal of Reproduction and Fertility 43, 149-152.
Veldhuis, J.D., Rodgers, R.J. \& Furlanetto, R.W. (1986) Synergistic actions of estradiol and the insulinlike growth factor somatomedin-C on swine ovarian (granulosa) cells. Endocrinology 119, 530-538.

World Health Organization (1987) WHO Laboratory Manual for the Examination of Human Semen and Semen-cervical Mucus Interaction. Cambridge University Press, Cambridge.

Zeleznik, A. \& Roth, J. (1978) Demonstration of the insulin receptor in vivo in rabbits and its possible role as a reservoir for the plasma hormone. Journal of Clinical Investigation 21, 1363-1374.

Received 14 October 1991 